\title{
Polyethylene microplastics are ingested and induce biochemical changes in Culex quinquefasciatus (Diptera: Culicidae) freshwater insect larvae
}

\author{
Malafaia, G. ${ }^{* *}$; da Luz, T.M. ${ }^{1}$; Guimarẽes, A.T.B. ${ }^{1} \&$ Araújo, A.P.C. ${ }^{2}$ \\ 'Departamento de Ciências Biológicas, Instituto Federal Goiano - Campus Urutaí (Urutaí, GO, Brazil). \\ ${ }^{2}$ Departamento de Biologia Geral, Universidade Federal de Goiás - Campus Samambaia (Goiânia, GO, Brazil).
}

Received October 07, 2020; Accept December 01, 2020

\begin{abstract}
Although microplastics' (MPs) toxicity has been reported in several aquatic and terrestrial organisms, the knowledge about how these pollutants can affect insects at the early developmental stage remains incipient. Thus, the aim of this study was to use Culex quinquefasciatus larvae as a model system to test the hypothesis that, besides accumulating in animals, polyethylene microplastics (PE MPs) lead to biochemical changes predictive of nutritional impacts, as well as induce oxidative stress, redox state imbalance, and neurotoxicity in them. Our results have indicated that short exposure to PE MPs ( 5 days) at the environmental concentration of $4.24 \times 10^{6}$ particles $\mathrm{m}^{-3}$ induced changes suggesting damage to energy metabolism such as reduced total proteins, total soluble carbohydrates, and triglycerides levels. In addition, increased thiobarbituric acid reactive species, in association with reduced total glutathione and DPPH radical scavenging activity (\%) have suggested an imbalance between oxide-reducing agents and antioxidant defense system, induced by pollutant. On the other hand, increased acetylcholinesterase activity has suggested the neurotoxic effect of PE MPs. Finally, PE MPs have accumulated in the larvae, and it may have been a triggering factor for the observed changes. Thus, our study has confirmed the potential of C. quinquefasciatus larvae to act as vector of MPs in different ecosystems and helped improving the knowledge about how PE MPs can affect their development and lead to losses in different ecological functions of this species.
\end{abstract}

Keywords: Micropollutants, insects, freshwater, life stage, developmental toxicity.

\section{INTRODUCTION}

The disposal of plastic waste in aquatic ecosystems is associated with the exponential increase in the consumption of products that use them as raw material (Macintosh et al., 2020). However, although this consumption moves millions of dollars and enables the economic growth of different countries (Patel et al., 1998; Van Eygen et al., 2018; Foschi \&
Bonoli, 2019), the incorrect disposal of these materials in the environment has been associated with significant effects on human health (Manzoor et al., 2020) and on other organisms (Bradney et al., 2019; Naidoo \& Rajkaran, 2020). Part of this issue refers to the effects of weathering on larger plastic waste discarded in the environment, namely: changes in physical properties, discoloration, surface erosion, loss of gloss and/or increase in haze, often caused by the oxidation and cleavage 
of polymer chains, which is a process that makes them potentially toxic (Pickett, 2018). In addition, these materials can get to aquatic systems as particles initially synthesized in small diameters (Anbumani \& Kakkar, 2018), such as plastic resin pellets (Ogata et al., 2009) and/or nanospheres used in hygiene and cosmetic products (Fendal \& Sewell, 2009).

The effects of microplastics (MPs) on the biota living in freshwater environments remains an incipient investigation field. Although these environments are recognized as input of MPs into the ocean, the knowledge about their effects on freshwater organisms remains limited (Eerkes-Medrano et al., 2015) in comparison to the consolidated knowledge about marine organisms (Andrady, 2011; Nelms et al., 2018; Bessa et al., 2018). Another gap in this knowledge concerns investigations about the effects of MPs on animals at early developmental stages, especially those exclusively aquatic (LeMoine et al., 2018; Malafaia et al., 2020) or species whose juveniles develop in water and adult individuals live in terrestrial environments (Al-Jaibachi et al., 2018). According to several researchers, the early life stages of different organisms are highly sensitive to different contaminants and pollutants (Pašková et al., 2011; Mesquita et al., 2015; Schweizer et al., 2018); besides, they are critical for the normal development of individuals.

Insects such as mayflies, dragonflies, midges, and mosquitoes are a group of animals whose initial development takes place exclusively in freshwater environments (Dijkstra et al., 2014); thus, their exposure to MPs may impair different ecological functions performed by these invertebrates (Oliveira et al., 2019). In addition, trophic transfer to other aquatic animals can disseminate MPs in river ecosystems and affect higher trophic levels in the food chain (Araújo \& Malafaia, 2021). On the other hand, the contamination of these insects with MPs can be a "gateway" to terrestrial ecosystems, either due to their transfer to the adult life stages of invertebrates (enabling the aerial dissemination of these pollutants) or to trophic transfer between terrestrial animals.

Al-Jaibachi et al. (2018) have recently shown that mosquito larvae can feed on MPs found in the water they live in, either because they cannot see the difference between food and microplastics, or due to scarcity of food resources, which can be temporary or permanent. In addition, these authors reported that as Culex pipiens larvae grew into adults, much of these MPs remained in them, a fact that corroborates the hypothesis that MPs are transferred to adult life. Cuthbert et al. (2019) have shown that water contamination with carboxylate-modified polystyrene MPs was not a limiting factor for the oviposition of $C$. pipiens mosquitoes. In addition, according to reports, small plastic particles can be used as oviposition sites for the ocean-skater insect species Halobates micans; thus, such particles can have a positive effect on the abundance and dispersion of this species (Majer et al., 2012). Together, these studies have shown that insect larvae, either from freshwater or marine environments, can thrive in environments contaminated with MPs.
However, despite this evidence, little is known about the effects induced by MPs on mosquito larvae, since these pollutants can impair their development and even prevent the emergence of adult pupae insects, thus significantly affecting their natural populations and ecological functions [e.g.: food chain, pollination, population control in different species, among others (Fang, 2010)]. Although Al-Jaibachi et al. (2018) have shown the plausibility of MPs accumulation in mosquito larvae, they did not investigate the likely effects of these pollutants on animals. Thus, Culex quinquefasciatus larvae were used as a model system representing mosquito species that lay eggs in freshwater environments in order to test the hypothesis that MPs accumulate in animals and induce predictive biochemical changes such as nutritional impacts, oxidative stress, redox state imbalance, and neurotoxicity. Although our study is preliminary, it helped to improve the knowledge about how MPs can affect the biota living in freshwater environments, since it provided information that can be used to develop measures focused on mitigating or remedying water pollution.

\section{MATERIAL AND METHODS}

\section{Microplastics}

Polyethylene microplastics (PE MPs) (Sigma-Aldrich; CAS number 9002-88-4, density $0.94 \mathrm{~g} \mathrm{~mL}^{-1}$; purity $>99 \%$ ) were the material of choice because they are some of the most used polymers in plastic material production (Horton et al., 2017). MPs used comprised a mixture of microspheres and fragments of varying sizes [diameter: $35.46 \mu \mathrm{m} \pm 18.17 \mu \mathrm{m}($ mean $\pm \mathrm{SD})]$ and different shapes [see complete chemical characterization in Araújo et al. (2020)]; such particles approximate the variety of shapes and sizes of MPs dispersed in the natural environment (Kooi \& Koelmans, 2019). A stock solution was prepared $\left(500 \mathrm{mg} \mathrm{mL} \mathrm{m}^{-1}\right.$ of PE MP in reconstituted purified water via reverse osmosis) based on Malafaia et al. (2020), and it originated the tested concentration. However, we must admit that stock-solution handling and animal exposure processes were not carried out in germ free, pyrogenic, or DNase/RNase-free environment. All procedures were performed in a conventional laboratory environment.

\section{Animals and experimental design}

Initially, Culex quinquefasciatus larvae were obtained from a semi-natural breeding site maintained at the Aquarium of Aquatic Animals of the Biological Research Laboratory at Instituto Federal Goiano - Urutaí Campus, according to Gerberg et al. (1994) and adopted by Alves et al. (2018, 2020). Briefly, the females lay on plastic trays $(50 \mathrm{~cm} \times 40$ $\mathrm{cm}$ x $25 \mathrm{~cm}$ ) covered with mesh Sombrite ${ }^{\circledR} 60 \%$, containing $25 \mathrm{~L}$ of deionized water and $20 \mathrm{~g}$ of feed used to feed mice. This species was selected due to its distribution worldwide and broad habitat preference (Samy et al., 2016; Alaniz et 
al., 2019). Furthermore, these larvae have good adaptability to laboratory conditions and have been used in different toxicological studies (Jebanesan et al., 2020; Belevich et al., 2020; Maia et al., 2020), which characterizes them as a good animal model.

After reaching the fourth instar, larvae were distributed in the following treatments: control group $(\mathrm{C})$, whose exposure water was free from PE MPs; and PE MP group, whose exposure water was added with PE MPs at the concentration of $4.24 \times 10^{6}$ particles $\mathrm{m}^{-3}$. According to Koelmans et al. (2019), this concentration can be potentially identified in freshwater and drinking water; thus, it brings the experimental design closer to a realistic environmental condition.

The volume of the stock solution added to the exposure waters was determined from the count of the particles in the stock solution and their correspondence to the nominal concentration $\left(500 \mathrm{mg} \mathrm{mL}^{-1}\right)$. For that, ten samples of $100 \mu \mathrm{L}$ were diluted in $100 \mathrm{~mL}$ of $70 \%$ alcohol and, later, filtered in a vacuum pump. Then, the membranes were dried and taken to the fluorescence microscope to estimate the number of particles per $\mathrm{mL}$. Such analysis was conducted based on the methodology recommended by Technical Standard n. L5.303 by the Environmental Sanitation Technology Company (CETESB) (Companhia de Tecnologia De Saneamento Ambiental (CETESB, 2005), with modifications, to count organisms and cells. The number of MPs recorded in the ImageJ software was multiplied by the counting factor $(\mathrm{F})$ given by equation $\mathrm{F}=\mathrm{A} / \mathrm{na}$; wherein: "A" is the total area of the paper filter $\left(1589.625 \mathrm{~mm}^{2}\right)$, " $\mathrm{n}$ " is the number of analyzed quadrants ( $n=10 /$ filter) and "a" is the area of each quadrant $\left(9 \mathrm{~mm}^{2}\right)$. This procedure allowed obtaining the predictive number of particles per $\mathrm{mL}$.

Each repetition (fourteen per treatment) comprised two C. quinquefasciatus larvae, which were kept in beakers filled with $25 \mathrm{~mL}$ of naturally dechlorinated water for five consecutive days under static exposure system (i.e., without aeration and water renewal) (temperature: $25-26^{\circ} \mathrm{C} ; 12 / 12$ $\mathrm{h}$ light/dark cycle). Treatments were randomly assigned to a certain position on the laboratory bench throughout the experiment (distance between beakers: $8 \mathrm{~cm}$ ). At the end of the experiment, larvae were separated in previously cleaned microtubes and stored at $-80^{\circ} \mathrm{C}$ until biochemical analysis and PE MPs quantification, which took place $24 \mathrm{~h}$ and $48 \mathrm{~h}$ after the end of the experiment, respectively.

\section{Toxicity biomarkers}

Biomarkers predictive of nutritional deficit, oxidative stress, and interferences in animals' antioxidant systems were used to assess the toxicity of PE MPs in C. quinquefasciatus larvae. Samples were prepared as previously described by Guimarães et al. (2021), with some modifications. Each larva was macerated in $450 \mu \mathrm{L}$ of phosphate buffered saline (PBS), and centrifuged at $13,000 \mathrm{rpm}$ and $4^{\circ} \mathrm{C}$, for $5 \mathrm{~min}$; supernatants were separated into aliquots, which were used in different biochemical evaluations. All tests were performed in ELISA microplate (96 wells). The percentage of larvae evolved into pupal stage was calculated.

\section{Assessment of nutritional status}

The nutritional status of the investigated animals was assessed, assuming that exposure to MPs could induce disorders in energy metabolism. Thus, total protein, carbohydrate, and triglycerides levels were evaluated, according to Souza et al. (2019). Commercial kits were used to determine total proteins and triglycerides concentrations, based on Lowry et al. (1951) method and the enzymatic colorimetric method by using glycerol-3-phosphate oxidase (GPO) (Sullivan et al., 1985). Total carbohydrate concentration was assessed according to Dubois et al. (1956); anhydrous glucose solutions (Equiplex Indústria Farmacêutica Ltda, Aparecida de Goiânia, Brazil) were used to determine the standard curve and to find the straight equation, similarly to Nielsen (2010), Jain et al. (2017), and Souza et al. (2019).

\section{Oxidative stress parameters}

\section{Nitric oxide measurement}

Griess colorimetric reaction was used to measure nitric oxide concentrations; this assay consisted of detecting nitrite resulting from NO oxidation, based on Ajjuri \& O'Donnell (2013). Nitrite levels were measured based on the Griess method (Grisham et al., 1998), with some adaptations. According to this technique, $30 \mu \mathrm{L}$ of each sample (in triplicate) was pipetted (in triplicate) into ELISA microplate wells filled with $150 \mu \mathrm{L}$ of Griess reagent [2.3\% sulfanilamide - N- (1-naphthyl) and subsequently added to $0.12 \%$ ethylenediamine and orthophosphoric acid $(0.5 \mathrm{~mol}$ $\left.\mathrm{L}^{-1}\right)$ in purified water via reverse osmosis]. Next, the Griess sample/reagent mixture was incubated at room temperature $\left(25-26^{\circ} \mathrm{C}\right)$ for $5 \mathrm{~min}$ and read in a microplate reader (Heales, model MB-580) at $492 \mathrm{~nm}$. Sodium nitrite solutions obtained from a stock solution were prepared in triplicate at the concentrations of $50,100,200,300,400$, and $500 \mu \mathrm{mol} \mathrm{L}^{-1}$, to find the standard curve. Linear regression analysis $(\mathrm{y}=$ $\left.0.0014 \mathrm{x}+0.0275 ; \mathrm{r}^{2}=0.99\right)$ was used to calculate nitrite concentrations in the samples.

\section{Thiobarbituric acid reactive species (TBARS)}

Thiobarbituric acid reactive species (TBARS) is widely adopted as lipid redox state measurement method (Draper \& Hadley, 1980). TBARS test was performed based on Pothiwong et al. (2007) and Carvalho et al. (2019), with some modifications. First, $100 \mu \mathrm{L}$ of tissue supernatants were mixed with $50 \mu \mathrm{L}$ of trichloroacetic acid (TCA) $(28 \% \mathrm{w} / \mathrm{v}$ in $0.25 \mathrm{~N}$ $\mathrm{HCl}$ ), $50 \mu \mathrm{L}$ of thiobarbituric acid (TBA, $1 \%$ in $0.25 \mathrm{~N}$ acetic acid) and $25 \mu \mathrm{L}$ of butylhydroxytoluene (BHT, $5 \mathrm{mM}$ ). Next, samples were incubated in water bath at $95^{\circ} \mathrm{C}$, for $15 \mathrm{~min}$; subsequently, they were centrifuged at $13,000 \mathrm{rpm}$, at room 
temperature $\left(25-26^{\circ} \mathrm{C}\right)$, for $10 \mathrm{~min}$. Supernatants deriving from the samples were transferred to ELISA microplate (in triplicate) and read at $492 \mathrm{~nm}$.

\section{Hydrogen peroxide measurement}

Hydrogen peroxide measurement was based on the colorimetric method used to determine the millimolar quantities of hydrogen peroxide [similarly to Graf \& Penniston (1980)], on iodide oxidation in the presence of ammonium molybdate, as well as on the photometry of the resulting blue starch -iodine complex, by using commercial kit (Kit Elabscience, Cat.: E-BC-K 102-S. Lot: 731RIHZ1ES. Exp: 2020-06-16).

\section{Antioxidant activity parameters}

\section{Total glutathione content (GSH + GSSG)}

The total glutathione content (reduced $(\mathrm{GSH})+$ oxidized (GSSG)) was determined based on the method described by Griffith (1980) and Carvalho et al. (2018). Dosing was performed in ELISA microplate, whose wells were initially added with $5 \mu \mathrm{L}$ of samples and $75 \mu \mathrm{L}$ of working mixture $(95$ mM phosphate buffer, 0.95 mM EDTA, $48 \mu \mathrm{M}$ NADPH, 0.031 $\mathrm{mg} \mathrm{mL} \mathrm{mL}^{-1} \mathrm{DTNB}, 0.115$ units $/ \mathrm{mL}$ glutathione reductase and $0.24 \%$ sulfosalicylic acid). Next, the samples were incubated at room temperature $\left(25-26^{\circ} \mathrm{C}\right)$ for $5 \mathrm{~min}$. Subsequently, $25 \mu \mathrm{L}$ of NADPH $\left(0.16 \mathrm{mg} \mathrm{mL}^{-1}\right)$ was added to the wells; absorbance was measured at $405 \mathrm{~nm}$ right after the reaction started. Five readings were performed at 1-min intervals between readings.

\section{Total superoxide dismutase (SOD) activity}

Total superoxide dismutase (SOD) activity was measured in the supernatants, based on the method described by Dieterich et al. (2000), with some modifications. Measurements were based on SOD's ability to scavenge superoxide radical anion, which decreases the overall pyrogallol autoxidation rate. One SOD activity unit was defined as the amount of enzymes inhibiting the pyrogallol autoxidation rate by $50 \%$, which was determined at $630 \mathrm{~nm}$. Results were expressed in $\mathrm{U} \mathrm{mg}^{-1}$ of protein (Lowry et al. (1951).

\section{Diphenyl-1-picrylhydrazyl (DPPH) radicals'scavenging activity}

DPPH stable radical assay was performed in compliance with Brand-Williams et al. (1995). The reaction mixture comprising $200 \mu \mathrm{L}$ of DPPH solution (prepared in $95 \%$ ethanol) $(100 \mathrm{mM})$ and $50 \mu \mathrm{L}$ of each test sample (supernatant) were incubated at room temperature $\left(25-26^{\circ} \mathrm{C}\right)$ for 30 minutes; absorbance was measured at $492 \mathrm{~nm}$. Ethanolic DPPH solution $(100 \mathrm{mM})$ was used as control and DPPH radical scavenging activity rate was calculated based on the following equation (Zarban et al., 2009; Chaves et al., 2019): DPPH radical scavenging activity $(\%)=[($ control absorbance - sample absorbance)/control absorbance] x 100 .

\section{Neurotoxicity parameter}

The acetylcholinesterase (AChE) activity was determined in microplate, based on Ellman's spectrophotometric method (Ellman, 1961) and Raja et al. (2019), by using iodized acetylcholine substrate and 5,5'-dithiobis (2-nitrobenzoic acid) (DTNB). Fifty (50) $\mu \mathrm{L}$ of each sample were added (in sequence) to each microplate well, as well as $100 \mu \mathrm{L}$ of iodinated acetylcholine substrate solution $\left(750 \mu \mathrm{g} \mathrm{mL}^{-1}\right)$ and $100 \mu \mathrm{L}$ of DTNB solution $\left(130 \mu \mathrm{g} \mathrm{mL}^{-1}\right)$. Next, absorbance was measured 30 seconds after reagents' homogenization and 3 minutes after the first reading in microplate reader, at 405 nm (Heales, model MB-580).

\section{PE MPs accumulation in C. quinquefasciatus larvae tissues}

PE MPs accumulation process was based on the methodology adopted by Ding et al. (2020), with some modifications. Larvae were digested in $10 \mathrm{~mL}$ of $\mathrm{KOH}$ solution $\left(100 \mathrm{~g} \mathrm{~L}^{-1}\right)$ at $60^{\circ} \mathrm{C}$ for $15 \mathrm{~h}$ and, subsequently, they were placed in water bath, at $80^{\circ} \mathrm{C}$, for $2 \mathrm{~h}$. According to Li et al. (2018), this solution did not have any effect on the morphology and composition of the analyzed MPs; it is the reason why it was selected among the previously published alternatives. The standard curve was generated based on serial dilutions of PE-MPs suspensions (3.125, 6.25, 12.5, 25, and $50 \mathrm{mg} \mathrm{mL}^{-1}$ ), which were previously treated with ultrasonic vibration for $30 \mathrm{~min}$, in addition to the blank (i.e., only $\mathrm{KOH}$ ). These suspensions were subjected to the same digestion process applied to biological samples. Aliquots of $250 \mu \mathrm{L}$ of solution were pipetted into ELISA microplate and $20 \mu \mathrm{L}$ of Nile red fluorescent dye [Sigma-Aldrich, CAS number 738567-3] prepared according to Maes et al. (2017) were added to each well. Next, samples were read in ELISA microplate reader (Heales, model MB-580) at $630 \mathrm{~nm}$. All assays were run in triplicate to confirm the accuracy of the standard curves. Background fluorescence of control C. quinquefasciatus larvae tissues was identified and subtracted from that of MPstreated samples. The background fluorescence of the digestion solution (i.e., blank) was identified and subtracted from that of MPs-treated samples and standard PE-MPs suspensions.

\section{Visual assessment of PE MPs in C. quinquefasciatus larvae}

Three random individuals were observed under fluorescence microscope (BEL Engineering ${ }^{\circledR}$, model FLUO3), at 40x magnification, according to Malafaia et al. (2020). A blue filter (excitation $450-490 \mathrm{~nm}$ ) was used to differentiate MPs images from possible particles fluoresced under green filter (excitation 510-560 nm).

\section{Statistical analysis}

Data were initially subjected to Shapiro-Wilk normality test. Parametric data were subjected to Student's t-test, 
whereas the non-parametric ones were subjected to Mann Whitney test, both at $5 \%$ probability level. Statistical analysis and graph plotting were conducted in GraphPad Prism software (version 7.0).

\section{RESULTS}

Although no animal has died throughout the experiment, the control group recorded a higher percentage of larvae evolved to the pupal stage $(62.5 \%)$ than the group exposed to PE MPs (37.5\%). In addition, PE MPs presented large accumulation in animals, mainly in their gastrointestinal tract (Figure 1C-G), which recorded a mean MP concentration of $1.055 \pm 0.391 \mathrm{ng} / \mathrm{larvae}$.

Biochemical analyses have shown that PE MPs accumulation was possibly linked to total protein (Figure 2A), triglycerides (Figure 2B), and total soluble carbohydrate levels (Figure 2C); these parameters decreased in larvae exposed to pollutants. There was a significant increase in thiobarbituric acid reactive species (Figure 2D) and a decrease in hydrogen peroxide levels (Figure 2E). However, oxide and nitric oxide levels did not change (Figure 2F).

Regarding to antioxidant activity parameters, PE MPs have significantly suppressed total glutathione (Figure 3A) and DPPH radical scavenging activity (\%) levels (Figure 3B). However, superoxide dismutase activity did not differ between treatments (Figure 3C), whereas AChe activity increased significantly in larvae exposed to PE MPs (Figure 3D).


Figure 1. Photomicrographs of Culex quinquefasciatus larvae exposed, or not, to PE MPs under fluorescence microscope. (A-B) Larvae in the control group; (C-D) larvae exposed to PE MPs at ventral and (E-G) dorsal view. 1: head; 2: eye; 3: chest; 4: abdomen and 5: abdominal segments. PE MPs are highlighted in yellow along the gastrointestinal tract of larvae. 

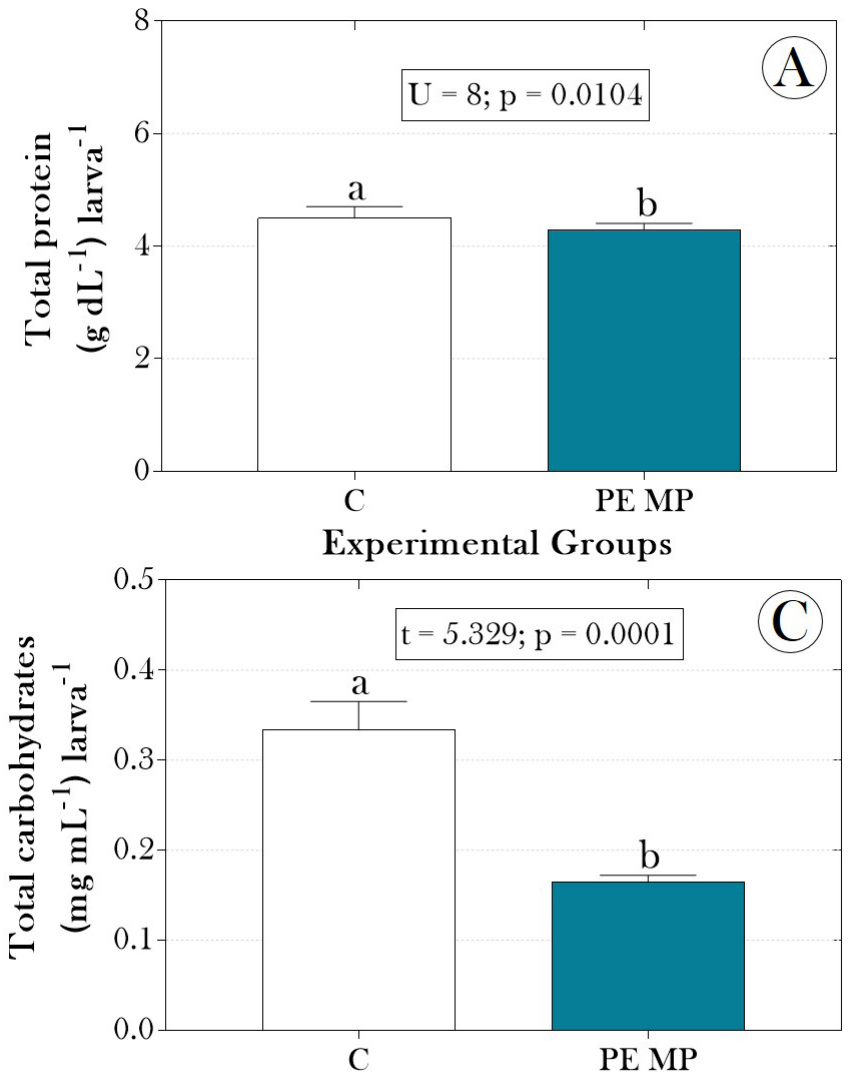

Experimental Groups

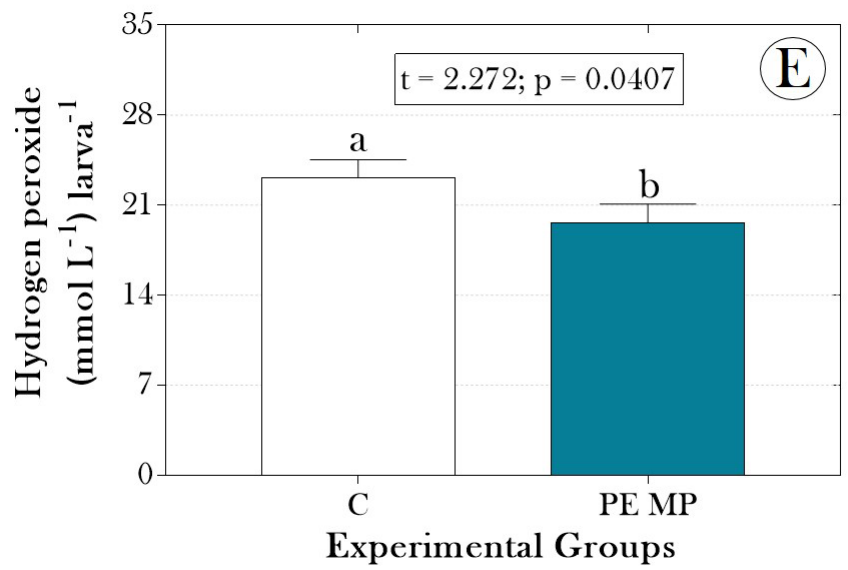

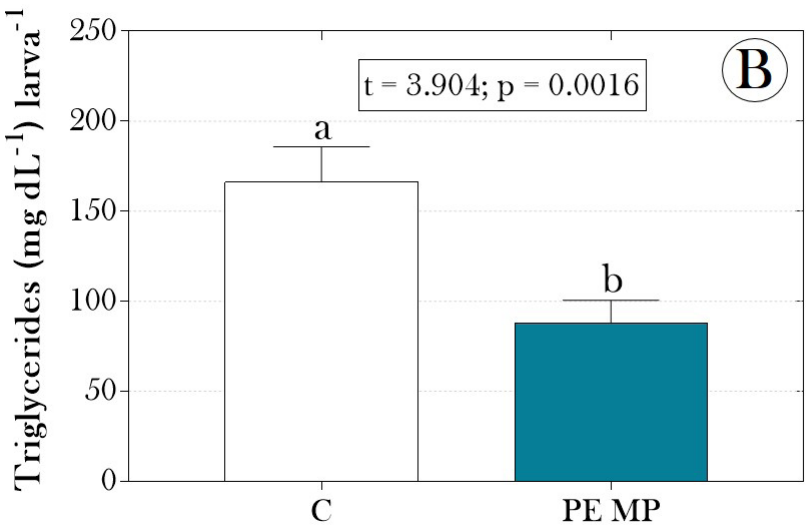

Experimental Groups

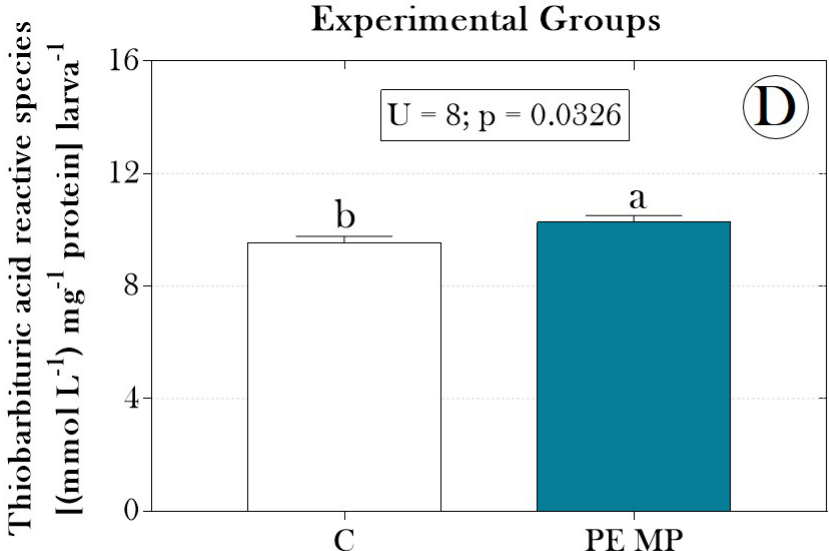

Experimental Groups

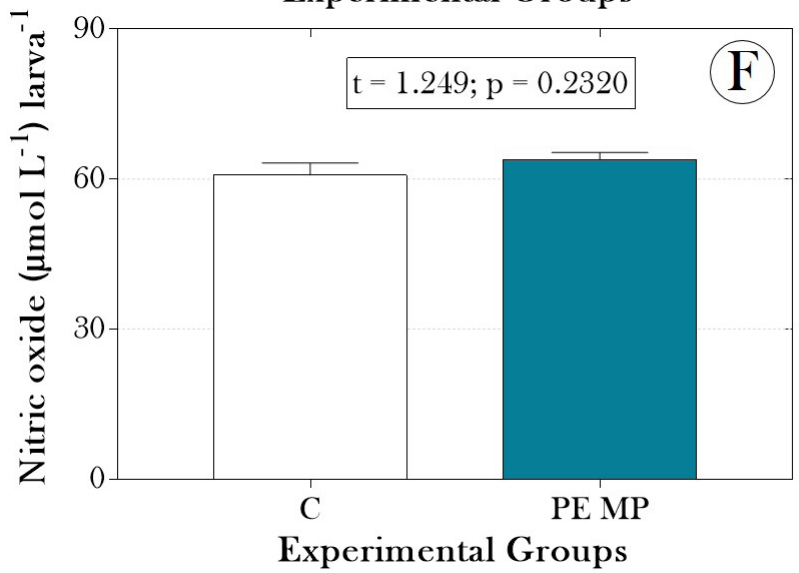

Figure 2. (A) Total protein, (B) triglycerides, (C) total soluble carbohydrates, (D) thiobarbituric acid reactive species; (E) hydrogen peroxide and (F) nitric oxide concentrations in Culex quinquefasciatus larvae exposed, or not, to PE MPs.

studies conducted with other animal models, such as those conducted by Wright et al. (2013) (with marine worms), Watts et al. (2015) (who exposed Crab species Carcinus maenas) and Yin et al. (2018) (with marine jacopever species Sebastes schlegelii). Although specific action mechanisms of MPs were not the target of these studies or of the current one, the decrease observed in the values recorded for the evaluated parameters was probably associated with a combination of factors. Among them, one finds possible dyspepsia and physical injury in the digestive tissue induced by MPs, which led to changes in energy allocation and interference in mechanisms regulating larval satiety, as suggested by Yin et al. (2018). It is so because gastrointestinal tube filling may have reduced their motivation to feed, as reported in other animal models by Cedervall et al. (2012), Cole et al. (2013), and Cole et al. (2015).

It is plausible assuming that MPs have damaged the intestinal microbiota of $C$. quinquefasciatus larvae and impaired their nutrient assimilation process. The intestinal microbiota of insects can significantly contribute to the nutritional ecology due to its high biosynthetic and degradative ability (Douglas, 2009; Jang \& Kikuchi, 2020). Previous studies have shown that insect microbiota plays an important role in vitamin synthesis, essential amino acid, steroid, and carbohydrate metabolism; besides, it uses insulin pathway to promote insect growth and development (Shin et al., 2011; Douglas, 2014). Studies reporting that MPs induced intestinal 

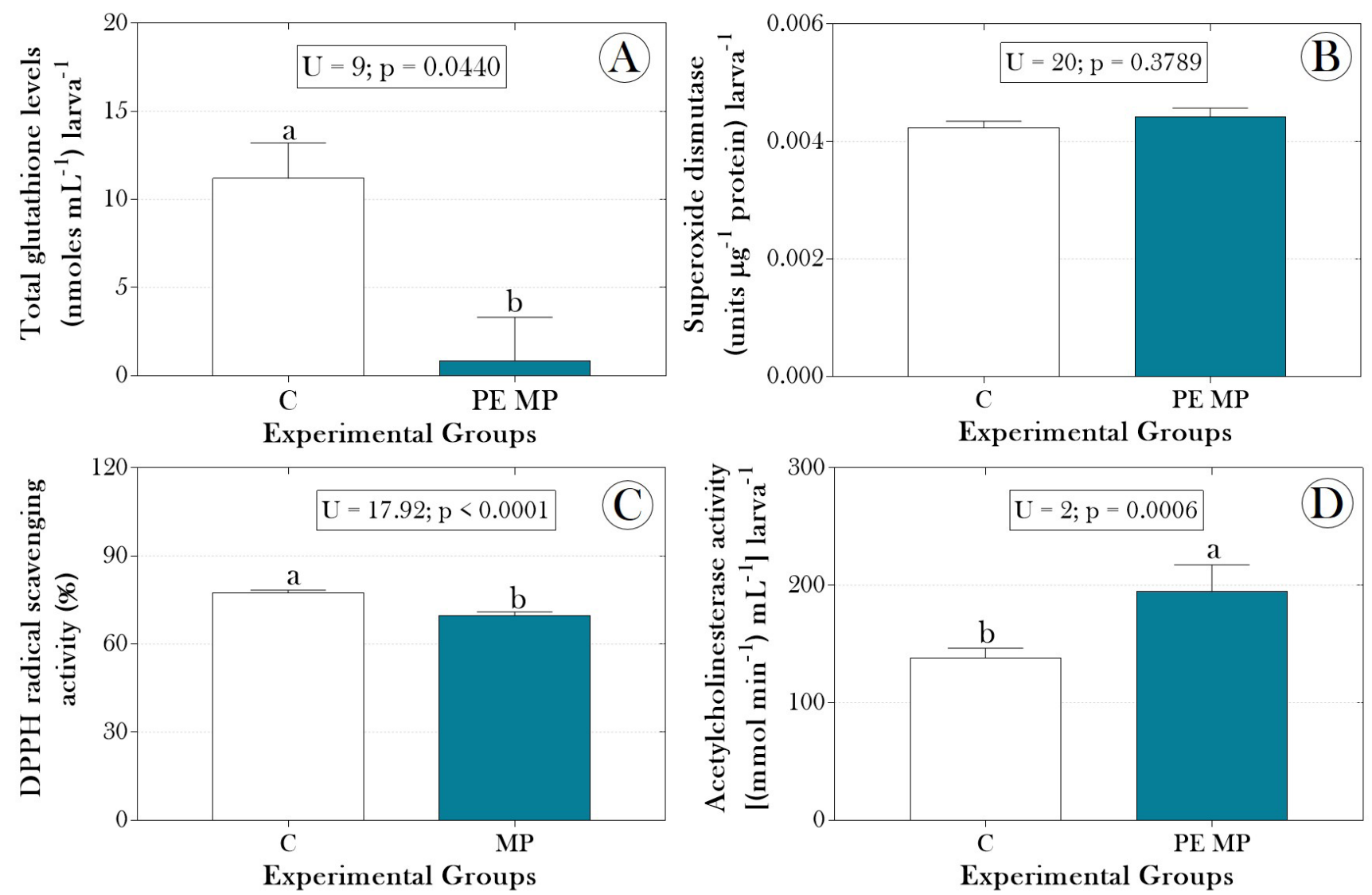

Figure 3. (A) Total glutathione; (B) DPPH radical scavenging activity (\%), (C) superoxide dismutase activity and (D) acetylcholinesterase levels in Culex quinquefasciatus larvae exposed, or not, to PE MPs.

dysbacteriosis and intestinal inflammation in mice ( $\mathrm{Li}$ et al., 2020), as well as lipid metabolism disorder (Lu et al., 2018), reinforce the hypothesis. Regardless of the action mechanism, a nutritional deficiency could explain the delayed development of larvae exposed to MPs, since nutrient assimilation plays a crucial role in larval development (Rivera-Pérez et al. (2017).

On the other hand, MPs are capable of inducing oxidative stress in animals, which can be harmful to the normal functioning of several physiological systems. The highest TBARS levels found in larvae exposed to PE MPs, in association with total glutathione activity and radical DPPH scavenging activity (\%) suppression, have evidenced the onset of imbalance between oxide-reducing agents and the antioxidant defense system directly or indirectly induced by MPs. According to Grotto et al. (2009), lipid peroxidation is a free-radical-mediated chain of reactions that, once triggered, leads to oxidative deterioration of polyunsaturated lipids. The most common targets lie on components of biological membranes; whenever propagated in biological membranes, these reactions can be triggered or enhanced by several toxic products, such as endoperoxides and aldehydes (Niki et al., 2005).

It is too early to suggest the physiological mechanisms involved in this redox imbalance, since antioxidant enzyme activity in aquatic invertebrates can increase or decrease in response to different environmental stressors capable of causing oxidative stress (Kim et al., 2010; Rhee et al., 2013; Kim et al., 2015; Jeong et al., 2017). Our results about glutathione differed from those reported by Jeong et al. (2017), who exposed marine copepod species to MPs and observed increased total glutathione activity; these authors suggested that intracellular ROS increase has induced signal transductions that activated antioxidant genes and enabled cells to be protected against oxidative stress. Moreover, MPs' size and type may play a crucial role in antioxidant activation mechanisms. Jeong et al. (2017) have investigated polystyrene microbeads of $0.05-, 0.5$ - and $6-\mu \mathrm{m}$, whereas the current study has investigated the toxicity of PE MPs with mean diameter of $35.46 \mu \mathrm{m} \pm 18.17 \mu \mathrm{m}$. In this case, instead of activating the transduction signals capable of activating and releasing glutathione synthesis, PE MPs may have blocked receptors on the surface of the membranes (via, e.g., formation of aggregated protein-MPs complexes), thus preventing molecular signaling in favor of the glutathione-mediated antioxidant defense. This may explain the inefficiency in sequestering the stable free radical 1,1-diphenyl-2-picrilhidrazil (DPPH•) observed in $C$. quinquefasciatus larvae exposed to PE MPs.

However, reduced hydrogen peroxide levels observed in larvae exposed to PE MPs may have reflected the action of other antioxidant enzymes known to act against this radical. It is the case of S-transferases, aldehyde dehydrogenases, 
and catalase, which act by preventing hydrogen peroxide accumulation. The role played by catalase activity in protecting against oxidative stress has already been demonstrated in $A$. aegyti (Oliveira et al., 2017).

Another change observed in this study concerns AChE activity, which is classically known to hydrolyze the neurotransmitter acetylcholine in cholinergic synapses (Colovic et al., 2013; Pang, 2014). Therefore, AChE plays a crucial role in all functions of living beings such as insects. PE MPs have induced a significant increase in the activity of this enzyme. Although this increase diverged from other studies which reported AChE activity inhibition induced by MPs and nanoplastics (NPs) (Oliveira et al., 2013, de Sá et al., 2015, Ferreira et al., 2016), possibly the lipid oxidative stress (inferred through increased TBARS levels) has caused the rupture of vesicle membranes containing acetylcholine in the presynaptic neurons of $C$. quinquefasciatus larvae exposed to PE MPs, which led to increased neurotransmitter release in cholinergic synaptic clefts and over-stimulation of postsynaptic receptors [see details of the molecular and cellular biology of cholinesterases in Massoulié et al. (1993)]. In addition, AChE production may have been induced to deal with oxidative stress and with the damages caused by PE MPs, since damaged cells and tissues are associated with a greater amount of acetylcholine than the healthy ones (Gambardella et al., 2017). Barboza et al. (2020) have recently reported increased AChE activity and lipid peroxidation (measured through TBARS) in the brain of Dicentrarchus labrax, Trachurus trachurus and Scomber colias presenting MPs in the intestine; this outcome reinforces the current hypotheses. The hypothesis that increased $\mathrm{AChE}$ activity in these animals is associated with positive regulation of the AChE gene, due to the inhibitory effect of pollutants, is suggested for future studies.

\section{CONCLUSION}

In conclusion, the PE MPs are capable of changing important biochemical parameters acting in the $C$. quinquefasciatus larval development. Our study showed that these microparticles induce nutritional deficit, oxidative stress, and acetylcholinesterase over-stimulation in $C$. quinquefasciatus, whose neurotoxic effects should be further investigated. Thus, our results open several perspectives for further investigations focusing PE MPs effects on insects. Assessing the impact of herein observed effects on the adult life of animals, as well as whether they are long-lasting or ephemeral, is a fertile investigation field.

\section{ACKNOWLEDGMENT}

This work was supported by funds from the Conselho Nacional de Desenvolvimento Científico e Tecnológico (CNPq) (Proc. N. 307743/2018-7 and Proc. N. 426531/2018-3) (Brazilian research agency) and Instituto Federal Goiano (Proc. N. 23219.000566.2020-33). Malafaia G. has a productivity scholarship from CNPq (Proc. N. 307743/2018-7).

\section{REFERENCES}

AJJURI, R.R. \& O’DONNELL, J.M. 2013. Novel wholetissue quantitative assay of nitric oxide Levels in Drosophila neuroinflammatory response. J. Vis. Exp., (82): 50892. http:// dx.doi.org/10.3791/50892

ALANIZ, A.J., CARVAJAL, M.A., BACIGALUPO, A. \& CATTAN, P. E. 2019. Global spatial assessment of Aedes aegypti and Culex quinquefasciatus: a scenario of Zika virus exposure. Epidemiol. Infect., 147: 1-11. http://dx.doi.org/10.1017/ S0950268818003102

AL-JAIBACHI, R., CUTHBERT, R. N. \& CALLAGHAN, A. 2018. Up and away: ontogenic transference as a pathway for aerial dispersal of microplastics. Biology Letters, 14(9): 20180479. https://doi.org/10.1098/rsbl.2018.0479

ALVES, K. F., CAETANO, F. H., GARCIA, I. J. P., SANTOS, H. L., SILVA, D. B., SIQUEIRA, J. M., TANAKA, A.S. \& Alves, S. N. 2018. Baccharis dracunculifolia (Asteraceae) essential oil toxicity to Culex quinquefasciatus (Culicidae). Environ. Sci. Pollut. Res. Int., 25(31): 31718-31726. http://dx.doi.org/10.1007/ s11356-018-3149-x

ALVES, S. N., PUJONI, D. G., MOCELIN, G., MELO, A. L., \& SERRÃO, J. E. 2020. Evaluation of Culex quinquefasciatus wings asymmetry after exposure of larvae to sublethal concentration of ivermectin. Environ. Sci. Pollut. Res. Int., 27(3): 3483-3488. http://dx.doi.org/10.1007/s11356-019-06963-5.

ANBUMANI, S. \& KAKKAR, P. 2018. Ecotoxicological effects of microplastics on biota: a review. Environ. Sci. Pollut. Res. Int., 25(15):14373-14396. http://dx.doi.org/10.1007/s11356-0181999-X.

ANDRADY, A. 2011. Microplastics in the marine environment. Mar. Pollut. Bull., 62(8): 1596-1605. https://doi.org/10.1016/j. marpolbul.2011.05.030

ARAÚJO, A.P.C., DE MELO, N.F.S., DE OLIVEIRA JUNIOR, A.G., RODRIGUES, F.P., FERNANDES, T., DE ANDRADE VIEIRA, J.E., ROCHA, T.L. \& MALAFAIA, G. 2020. How much are microplastics harmful to the health of amphibians? A study with pristine polyethylene microplastics and Physalaemus cuvieri. J. Hazard. Mater., 382: 121066. https://doi.org/10.1016/j. jhazmat.2019.121066

ARAÚJO, A.P.C. \& MALAFAIA, G. 2021. Microplastic ingestion induces behavioral disorders in mice: A preliminary study on the trophic transfer effects via tadpoles and fish. J. Hazard. Mater., 401: 123263. https://doi.org/10.1016/j.jhazmat.2020.123263

BARBOZA, L.G.A., LOPES, C., OLIVEIRA, P., BESSA, F., OTERO, V., HENRIQUES, B., RAIMUNDO, J., CAETANO, M. \& GUILHERMINO, L. 2020. Microplastics in wild fish from North East Atlantic Ocean and its potential for causing neurotoxic effects, lipid oxidative damage, and human health risks associated with ingestion exposure. Sci. Total Environ., 717: 134625. https://doi.org/10.1016/j.scitotenv.2019.134625

BELEVICH, O., YURCHENKO, Y., ALEKSEEV, A., KOTINA, O., ODEYANKO, V., TSENTALOVICH, Y., YANSHOLE, L., KRYUKOV, V., DANILOV, V. \& GLUPOV, V. 2020. Toxic effects of fine plant powder impregnated with avermectins on mosquito larvae and nontarget aquatic invertebrates. J. Med. Entomol., https://doi.org/10.1093/jme/tjaa227

BESSA. F., BARRÍA. P., NETO, J.M., FRIAS, J.P.G.L., OTERO, V., SOBRAL, P. \& MARQUES, J.C. 2018. Occurrence of microplastics in commercial fish from a natural estuarine environment. Mar. Pollut. Bull., 128: 575-584. http://dx.doi. org/10.1016/j.marpolbul.2018.01.044.

BRADNEY, L., WIJESEKARA, H., PALANSOORIYA, 
K.N., OBADAMUDALIGE, N., BOLAN, N.S., OK, Y.S., RINKLEBE, J. \& KIRKHAM, M.B. 2019. Particulate plastics as a vector for toxic trace-element uptake by aquatic and terrestrial organisms and human health risk. Environ. Int., 131: 104937. https://doi.org/10.1016/j.envint.2019.104937.

BRAND-WILLIAMS, W., CUVELIER, M.E. \& BERSET C. 1995. Use of a free radical method to evaluate antioxidant activity. J. Food. Sci. Tehnol., 28: 25-30.

CARVALHO, M.M.F., LAGE, N.N., PAULINO, A.H.S., PEREIRA, R.R., ALMEIDA, L.T., SILVA, T.F., MAGALHÃES, C.L.B., LIMA, W.G., SILVA, M.E., PEDROSA, M.L. \& GUERRA, J.F.C. 2019. Effects of açai on oxidative stress, ER stress, and inflammation-related parameters in mice with high fat diet-fed induced NAFLD. Sci. Rep., 9: 8107. https://doi.org/10.1038/ s41598-019-44563-y

CARVALHO, M.M.D.F., REIS, L.L.T., LOPES, J.M.M., LAGE, N.N., GUERRA, J.F.D.C., ZAGO, H. P., BONOMO, L.D.F., PEREIRA, R.R., LIMA, W.G., SILVA, M.E. \& PEDROSA, M. L. 2018. Açai improves non-alcoholic fatty liver disease (NAFLD) induced by fructose. Nutr. Hosp., 35(2): 318-325. http://dx.doi.org/10.20960/nh.1294

CEDERVALL, T., HANSSON, L.A., LARD, M., FROHM, B. \& LINSE, S. 2012. Food chain transport of nanoparticles affects behaviour and fat metabolism in fish. PLoS One 7: e32254. http://dx.doi.org/10.1371/journal.pone.0032254

CHAVES, J.O., DE FREITAS FERNANDES, A.M., PARREIRAS, P.M., BREGUEZ, G.S., PASSOS, M.C., da CUNHA, L.R. \& MENEZES, C.C. 2019. Effect of storage on retinol content and total antioxidant capacity of human milk. Br. Food J., 122(2) 606-116. http://dx.doi.org/10.1108/BFJ-05-2019-0334

COLE, M., LiNDEQUE, P., FILEMAN, E., HALSBAND, C. \& GALLOWAY, T.S. 2015. The impact of polystyrene microplastics on feeding, function and fecundity in the marine copepod Calanus helgolandicus. Environ. Sci. Technol., 49(2): 1130-1137. https://doi.org/10.1021/es504525u

COLE, M., LINDEQUE, P., FILEMAN, E., HALSBAND, C., GOODHEAD, R., MOGER, J. \& Galloway, T. S. 2013. Microplastic ingestion by zooplankton. Environ. Sci. Technol., 47(12): 6646-6655. http://dx.doi.org/10.1021/es400663f

COLOVIC, M.B., KRSTIC, D.Z., LAZAREVIC-PASTI, T.D., BONDZIC, A.M. \& VASIC, V.M. 2013. Acetylcholinesterase inhibitors: pharmacology and toxicology. Curr. Neuropharmacol., 11(3): 315-335. http://dx.doi. org/10.2174/1570159X11311030006

CUTHBERT, R.N., AL-JAIBACHI, R., DALU, T., DICK, J. T. \& CALLAGHAN, A. 2019. The influence of microplastics on trophic interaction strengths and oviposition preferences of dipterans. Sci. Total Environ., 651: 2420-2423. https://doi. org/10.1016/j.scitotenv.2018.10.108

DE SÁ, L.C., LUÍS, L.G. \& GUILHERMINO, L. 2015. Effects of microplastics on juveniles of the common goby (Pomatoschistus microps): confusion with prey, reduction of the predatory performance and efficiency, and possible influence of developmental conditions. Environ. Pollut., 196: 359-362. https://doi.org/10.1016/j.envpol.2014.10.026

DIETERICH, S., BIELIGK, U., BEULICH, K., HASENFUSS, G. \& PRESTLE, J. 2000. Gene expression of antioxidative enzymes in the human heart: increased expression of catalase in the endstage failing heart. Circulation, 101(1): 33-39. http://dx.doi. org/10.1161/01.cir.101.1.33

DIJKSTRA, K.D.B., MONAGHAN, M.T. \& PAULS, S.U. 2014. Freshwater biodiversity and aquatic insect diversification. Annu. Rev. Entomol., 59: 143-163. https://doi.org/10.1146/annurevento-011613-161958
DING, J., HUANG, Y., LIU, S., ZHANG, S., ZOU, H., WANG, Z., ZHU, W. \& GENG, J. 2020. Toxicological effects of nanoand micro-polystyrene plastics on red tilapia: Are larger plastic particles more harmless? J. of Hazard. Mater., 396:122693. https://doi.org/10.1016/j.jhazmat.2020.122693

DOUGLAS, A.E. 2009. The microbial dimension in insect nutritional ecology. Functional Ecology, 23(1): 38-47. https:// doi.org/10.1111/j.1365-2435.2008.01442.x

DOUGLAS, A.E. 2014. Molecular dissection of nutrient exchange at the insect-microbial interface. Curr. Opin. Insect Sci., 4: 23-28. https://doi.org/10.1016/j.cois.2014.08.007

DRAPER, H.H., POLENSEK, L., HADLEY, M. \& MCGIRR, L. G. 1984. Urinary malondialdehyde as an indicator of lipid peroxidation in the diet and in the tissues. Lipids, 19(11): 836 . http://dx.doi.org/10.1007/BF02534512

DUBOIS, M., GILLES, K.A., HAMILTON J.K., REBERS, P.A. \& SMITH, F. 1956. Colorimetric method for determination of sugars and related substances. Anal. Chem., 28: 350-356. https:// doi.org/10.1021/ac60111a017

EERKES-MEDRANO, D., THOMPSON, R.C. \& ALDRIDGE, D.C. 2015. Microplastics in freshwater systems: a review of the emerging threats, identification of knowledge gaps and prioritisation of research needs. Water Res., 75: 63-82. https:// doi.org/10.1016/j.watres.2015.02.012

ELLMAN, G.L., COURTNEY, K.D., ANDRES Jr, V. \& FEATHERSTONE, R.M. 1961. A new and rapid colorimetric determination of acetylcholinesterase activity. Biochem. Pharmacol., 7(2): 88-95. https://doi.org/10.1016/00062952(61)90145-9

FANG, J. 2010. Ecology: a world without mosquitoes. Nature News, 466(7305): 432-434. http://dx.doi.org/10.1038/466432a

FENDALL, L.S. \& SEWELL, M.A. 2009. Contributing to marine pollution by washing your face: microplastics in facial cleansers. Mar. Pollut. Bull., 58(8): 1225-1228. https://doi.org/10.1016/j. marpolbul.2009.04.025

FERREIRA, P., FONTE, E., SOARES, M. E., CARVALHO, F. \& GUILHERMINO, L. 2016. Effects of multi-stressors on juveniles of the marine fish Pomatoschistus microps: gold nanoparticles, microplastics and temperature. Aquat. Toxicol., 170: 89-103. https://doi.org/10.1016/j.aquatox.2015.11.011

FOSCHI, E. \& BONOLI, A. 2019. The commitment of packaging industry in the framework of the European strategy for plastics in a circular economy. Adm. Sci., 9(1): 18.

GAMBARDELLA, C., MORGANA, S., FERRANDO, S., BRAMINI, M., PIAZZA, V., COSTA, E., GARAVENTA, F. \& FAIMALI, M. 2017. Effects of polystyrene microbeads in marine planktonic crustaceans. Ecotoxicol. Environ. Saf., 145: 250-257. http://dx.doi.org/10.1016/j.ecoenv.2017.07.036

GERBERG, E.J., BARNARD, D.R. \& WARD, R.A. 1994. Manual for mosquito rearing and experimental techniques. American Mosquito Control Association, Inc..

GRAF, E. \& PENNISTON, J.T. 1980. Method for determination of hydrogen peroxide, with its application illustrated by glucose assay. Clin. Chem., 26(5), 658-660. http://dx.doi.org/10.1093/ clinchem $/ 26.5 .0658$

GRIFFITH, O.W. 1980. Determination of glutathione and glutathione disulfide using glutathione reductase and 2-vinylpyridine. Anal. Biochem., 106(1): 207-212. http://dx.doi.org/10.1016/00032697(80)90139-6

GRISHAM, M.B., GRANGER, D.N. \& LEFER, D.J. 1998. Modulation of leukocyte-endothelial interactions by reactive metabolites of oxygen and nitrogen: relevance to ischemic heart disease. Free Radic. Biol. Med., 25(4-5): 404-433. http://dx.doi. org/10.1016/s0891-5849(98)00094-x 
GROTTO, D., MARIA, L.S., VALENTINI, J., PANIZ, C., SCHMITT, G., GARCIA, S. C., POMBLUM, V.J., ROCHA, J.B.T. \& FARINA, M. 2009. Importance of the lipid peroxidation biomarkers and methodological aspects for malondialdehyde quantification. Quim. Nova, 32(1): 169-174. https://doi. org/10.1590/S0100-40422009000100032

GUIMARÃES, A.T.B., DE LIMA RODRIGUES, A.S., PEREIRA, P.S., SILVA, F.G. \& MALAFAIA, G. 2021. Toxicity of polystyrene nanoplastics in dragonfly larvae: An insight on how these pollutants can affect bentonic macroinvertebrates. Sci. Total Environ., 752: 141936. https://doi.org/10.1016/j. scitotenv.2020.141936

HORTON, A.A., WALTON, A., SPURGEON, D.J., LAHIVE, E. \& SVENDSEN, C. 2017. Microplastics in freshwater and terrestrial environments: evaluating the current understanding to identify the knowledge gaps and future research priorities. Sci. Total Environ., 586: 127-141. https://doi.org/10.1016/j. scitotenv.2017.01.190

JAIN, V.C., KARIBASAPPA, G.N., DODAMANI, A.S. \& MALI, G.V. 2017. Estimating the carbohydrate content of various forms of tobacco by phenol-sulfuric acid method. J. Health. Promot. Educ., 6: 90. http://dx.doi.org/10.4103/jehp.jehp_41_17

JANG, S. \& KIKUCHI, Y. 2020. Impact of the insect gut microbiota on ecology, evolution, and industry. Curr. Opini. Insect Sci., 41: 33-39. https://doi.org/10.1016/j.cois.2020.06.004.

JEBANESAN, A., BARANITHARAN, M., KOVENDAN, K. \& AVERY, P.B. 2020. Impact of Punica granatum-based green larvicide on the predation rate of Polypedates cruciger for the control of mosquito vectors, Anopheles stephensi and Culex quinquefasciatus (Diptera: Culicidae). Int. J. Trop. Insect Sci., 25: 1-11. https://doi.org/10.1007/s42690-020-00293-7

JEONG, C.B., KANG, H.M., LEE, M.C., KIM, D.H., HAN, J., HWANG, D.S. \& LEE, J.S. 2017. Adverse effects of microplastics and oxidative stress-induced MAPK/Nrf2 pathway-mediated defense mechanisms in the marine copepod Paracyclopina nana. Sci. Rep., 7(1): 1-11. https://doi.org/10.1038/srep41323

KIM, B.M., RHEE, J.S., LEE, K.W., KIM, M.J., SHIN, K.H., LEE, S.J. \& LEE, J.S. 2015. UV-B radiation-induced oxidative stress and p38 signaling pathway involvement in the benthic copepod Tigriopus japonicus. Comp. Biochem. Phys. C., 167: 15-23. https://doi.org/10.1016/j.cbpc.2014.08.003

KIM, K.T., KLAINE, S.J., CHO, J., KIM, S.H. \& KIM, S.D. 2010. Oxidative stress responses of Daphnia magna exposed to $\mathrm{TiO}_{2}$ nanoparticles according to size fraction. Sci. Total Environ., 408(10): 2268-2272. 10.1016/j.scitotenv.2010.01.041

KOELMANS, A.A., NOR, N.H.M., HERMSEN, E., KOOI, M., MINTENIG, S. M. \& DE FRANCE, J. 2019. Microplastics in freshwaters and drinking water: critical review and assessment of data quality. Water Res., 155: 410-422. https://doi.org/10.1016/j. watres.2019.02.054

KOOI, M. \& KOELMANS, A.A. 2019. Simplifying microplastic via continuous probability distributions for size, shape, and density. Environ. Sci. Technol. Lett., 6(9): 551-557. https://doi. org/10.1021/acs.estlett.9b00379

LEMOINE, C.M., KELLEHER, B.M., LAGARDE, R., NORTHAM, C., ELEBUTE, O. O. \& CASSONE, B.J. 2018. Transcriptional effects of polyethylene microplastics ingestion in developing zebrafish (Danio rerio). Environ. Pollut., 243: 591-600. http:// dx.doi.org/10.1016/j.envpol.2018.08.084

LI, B., DING, Y., CHENG, X., SHENG, D., XU, Z., RONG, Q. \& ZHANG, Y. 2020. Polyethylene microplastics affect the distribution of gut microbiota and inflammation development in mice. Chemosphere, 244: 125492. https://doi.org/10.1016/j. chemosphere.2019.125492
LOWRY, O.H., ROSEBROUGH, N.J., FARR, A.L. \& RANDALL, R.J. 1951. Protein measurement with the Folin phenol reagent. J. Biol. Chem., 193: 265-275.

LU, L., WAN, Z., LUO, T., FU, Z. \& JIN, Y. 2018. Polystyrene microplastics induce gut microbiota dysbiosis and hepatic lipid metabolism disorder in mice. Science of the Total Environment, 631: 449-458. https://doi.org/10.1016/j.scitotenv.2018.03.051

MACINTOSH, A., SIMPSON, A., NEEMAN, T. \& DICKSON, K. 2020. Plastic bag bans: lessons from the Australian capital territory. Resour. Conserv. Recy., 154: 104638. https://doi. org/10.1016/j.resconrec.2019.104638

MAES, T., JESSOP, R., WELLNER, N., HAUPT, K. \& MAYES, A.G. 2017. A rapid-screening approach to detect and quantify microplastics based on fluorescent tagging with Nile Red. Sci. Rep.: 7(1), 1-10. https://doi.org/10.1038/srep44501

MAIA, D.S., LOPES, C.F., SALDANHA, A.A., SILVA, N.L., SARTORI, Â.L.B., CAROLLO, C.A. \& DE SIQUEIRA, J.M. 2020. Larvicidal effect from different Annonaceae species on Culex quinquefasciatus. Environ. Sci. Pollut. Res., 27(29): 36983-36993. http://dx.doi.org/10.1007/s11356-020-08997-6

MAJER, A.P., VEDOLIN, M.C. \& TURRA, A. 2012. Plastic pellets as oviposition site and means of dispersal for the ocean-skater insect Halobates. Mar. Pollut. Bull., 64(6): 1143-1147. http:// dx.doi.org/10.1016/j.marpolbul.2012.03.029

MALAFAIA, G., DE SOUZA, A.M., PEREIRA, A.C., GONÇALVES, S., DA COSTA ARAÚJO, A.P., RIBEIRO, R.X. \& ROCHA, T. L. 2020. Developmental toxicity in zebrafish exposed to polyethylene microplastics under static and semistatic aquatic systems. Sci. Total Environ., 700: 134867. https:// doi.org/10.1016/j.scitotenv.2019.134867

MANZOOR, J., SHARMA, M., SOFI, I.R. \& DAR, A.A. 2020. Plastic Waste Environmental and Human Health Impacts. In Handbook of Research on Environmental and Human Health Impacts of Plastic Pollution (pp. 29-37). IGI Global.

MASSOUliÉ, J., SUSSMAN, J., BON, S. \& SILMAN, I. 1993. Structure and functions of acetylcholinesterase and butyrylcholinesterase. Prog. Brain Res., 98: 139-139. https://doi. org/10.1016/S0079-6123(08)62391-2

MESQUITA, S.R., VAN DROOGE, B.L., OLIVEIRA, E., GRIMALT, J.O., BARATA, C., VIEIRA, N., GUIMARÃES, L. \& PIÑA, B. 2015. Differential embryotoxicity of the organic pollutants in rural and urban air particles. Environ. Pollut., 206: 535-42. https://doi.org/10.1016/j.envpol.2015.08.008

NAIDOO, T. \& RAJKARAN, A. 2020. Impacts of plastic debris on biota and implications for human health: A South African perspective. S. Afr. J. Sci., 116(5-6): 1-8. http://dx.doi. org/10.17159/sajs.2020/7693

NELMS, S.E., GALLOWAY, T.S., GODLEY, B.J., JARVIS, D.S. \& LINDEQUE, P.K. 2018. Investigating microplastic trophic transfer in marine top predators. Environ. Pollut., 238: 999-1007. https://doi.org/10.1016/j.envpol.2018.02.016

NIELSEN, S.S. 2010. Phenol-sulfuric acid method for total carbohydrates. In Food analysis laboratory manual (pp. 47-53). Springer, Boston, MA, 2010.

NIELSEN, T.D., HASSELBALCH, J., HOLMBERG, K. \& STRIPPLE, J. 2020. Politics and the plastic crisis: A review throughout the plastic life cycle. Wiley Energy Environ., 9(1): e360. https://doi.org/10.1002/wene.360

NIKI, E., YOSHIDA, Y., SAITO, Y. \& NOGUCHI, N. 2005. Lipid peroxidation: mechanisms, inhibition, and biological effects. Biochem. Biophys. Res. Commun., 338(1): 668-676. http:// dx.doi.org/10.1016/j.bbrc.2005.08.072

OGATA, Y., TAKADA, H., MIZUKAWA, K., HIRAI, H., IWASA, S., ENDO, S., MATO, Y., SAHA, M., OKUDA, 
K., NAKASHIMA, A., MURAKAMI, M., ZURCHER, N., BOOYATUMANONDO, R., ZAKARIA, M.P., DUNG, Q., GORDON, M., MIGUEZ, C., SUZUKI, S., MOORE, C., KARAPANAGIOTI, H.K., WEERTS, S., MCCLURG, T., BURRES, E., SMITH, W., VAN VELKENBURG, M., LANG, J.S., LANG, R.C., LAURSEN, D., DANNER, B. \& STEWARDSON, N, Thompson RC. 2009. International Pellet Watch: global monitoring of persistent organic pollutants (POPs) in coastal waters. 1. Initial phase data on PCBs, DDTs, and HCHs. Mar. Pollut. Bull., 58(10): 1437-46. http://dx.doi.org/10.1016/j. marpolbul.2009.06.014.

OLIVEIRA, J.H.M., TALYULI, O.A., GONCALVES, R.L., PAIVA-SILVA, G.O., SORGINE, M.H.F., ALVARENGA, P.H. \& OLIVEIRA, P.L. 2017. Catalase protects Aedes aegypti from oxidative stress and increases midgut infection prevalence of Dengue but not Zika. PLOS Negl. Trop. Dis., 11(4): e0005525. http://dx.doi.org/10.1371/journal.pntd.0005525.

OLIVEIRA, M., AMEIXA, O.M. \& SOARES, A.M. 2019. Are ecosystem services provided by insects "bugged" by micro (nano) plastics? TrAC Trend. Anal. Chem., 113: 317-320. https://doi.org/10.1016/j.trac.2019.02.018

OLIVEIRA, M., RIBEIRO, A., HYLLAND, K. \& GUILHERMINO, L. 2013. Single and combined effects of microplastics and pyrene on juveniles $(0+$ group) of the common goby Pomatoschistus microps (Teleostei, Gobiidae). Ecol. Indic., 34: 641-647. https:// doi.org/10.1016/j.ecolind.2013.06.019

PANG, Y.P. (2014). Insect acetylcholinesterase as a target for effective and environmentally safe insecticides. In Advances in Insect Physiology (Vol. 46, pp. 435-494). Academic Press.

PAŠKOVÁ, V., HILSCHEROVÁ, K. \& BLÁHA, L. 2011. Teratogenicity and embryotoxicity in aquatic organisms after pesticide exposure and the role of oxidative stress. Ver. Environ. Contam. Toxicol., 211:25-61. https://doi.org/10.1007/978-14419-8011-3 2

PATEL, M.K., JOCHEM, E., RADGEN, P. \& WORRELL, E. 1998. Plastics streams in Germany-an analysis of production, consumption and waste generation. Resour. Conserv. Recy., 24(34): 191-215. http://dx.doi.org/10.1016/S0921-3449(98)00015-9

PICKETT, J.E. 2018. Chapter 8 - Weathering of plastics. In: Handbook of Environmental Degradation of Materials (Third Edition) (pp. 163-184). Elsevier, 2018.

POTHIWONG, W., LAORPAKSA, A., PIRARAT, N., SIRISAWADI, S., INTARAPANYA, J. \& JIANMONGKOL, S. 2007. Autoxidation of brain homogenates from various animals as measured by thiobarbituric acid assay. J. Pharmacol. Toxicol. Methods, 56(3): 336-338. http://dx.doi.org/10.1016/j. vascn.2007.08.004

RAJA, G.L., SUBHASHREE, K.D., LITE, C., SANTOSH, W. \& BARATHI, S. 2019. Transient exposure of methylparaben to zebrafish (Danio rerio) embryos altered cortisol level, acetylcholinesterase activity and induced anxiety-like behaviour. Gen. Comp. Endocrinol., 279: 53-59. http://dx.doi.org/10.1016/j. ygcen.2018.11.001

RHEE, J.S., YU, I. T., KIM, B.M., JEONG, C.B., LEE, K. W., KIM, M.J. \& LEE, J.S. 2013. Copper induces apoptotic cell death through reactive oxygen species-triggered oxidative stress in the intertidal copepod Tigriopus japonicus. Aquat. Toxicol., 132: 182-189. https://doi.org/10.1016/j.aquatox.2013.02.013

RIVERA-PÉREZ, C., CLIFTON, M. E. \& NORIEGA, F.G. 2017. How micronutrients influence the physiology of mosquitoes. Curr. Opini. Insect Sci., 23: 112-117. http://dx.doi.org/10.1016/j. cois.2017.07.002

SAMY, A.M., ELAAGIP, A.H., KENAWY, M.A., AYRES, C.F., PETERSON, A.T. \& SOLIMAN, D.E. 2016. Climate change influences on the global potential distribution of the mosquito Culex quinquefasciatus, vector of West Nile virus and lymphatic filariasis. PloS One, 11(10): e0163863. https://doi.org/10.1371/ journal.pone. 0163863

SCHWEIZER, M., DIETERICH, A., CORRAL MORILLAS, N., DEWALD, C., MIKSCH, L., NELSON, S., WICK, A., TRIEBSKORN, R. \& KÖHLER, H.R. 2018. The importance of sediments in ecological quality assessment of stream headwaters: embryotoxicity along the Nidda River and its tributaries in Central Hesse, Germany. Environ. Sci. Eur., 30(1): 22. http:// dx.doi.org/10.1186/s12302-018-0150-4.

SHIN, S.C., KIM, S.H., YOU, H., KIM, B., KIM, A.C., LEE, K.A. \& LEE, W.J. 2011. Drosophila microbiome modulates host developmental and metabolic homeostasis via insulin signaling. Science, 334(6056): 670-674. http://dx.doi.org/10.1126/ science. 1212782

SOUZA, R.S., VIRGINIO, F., RIBACK, T. I. S., SUESDEK, L., BARUFI, J. B. \& GENTA, F.A. 2019. Microorganism-based larval diets affect mosquito development, size and nutritional reserves in the yellow fever mosquito Aedes aegypti (Diptera: Culicidae). Front. Physiol., 10: 152. https://doi.org/10.3389/ fphys.2019.00152

SULLIVAN, D.R., KRUIJSWIJK, Z., WEST, C.E., KOHLMEIER, M. \& KATAN, M.B. 1985. Determination of serum triglycerides by an accurate enzymatic method not affected by free glycerol. Clin. Chem., 31(7): 1227-1228.

VAN EYGEN, E., LANER, D. \& FELLNER, J. 2018. Circular economy of plastic packaging: Current practice and perspectives in Austria. Waste Manage., 72: 55-64. https://doi.org/10.1016/j. wasman.2017.11.040

WATTS, A.J., URBINA, M.A., CORR, S., LEWIS, C. \& GALLOWAY, T.S. 2015. Ingestion of plastic microfibers by the crab Carcinus maenas and its effect on food consumption and energy balance. Environ. Sci. Technol., 49(24): 14597-14604. https://doi.org/10.1021/acs.est.5b04026

WRIGHT, S.L., ROWE, D., THOMPSON, R.C. \& GALLOWAY, T.S. 2013. Microplastic ingestion decreases energy reserves in marine worms. Curr. Biol., 23(23): R1031-R1033. https://doi. org/10.1016/j.cub.2013.10.068

YIN, L., CHEN, B., XIA, B., SHI, X. \& QU, K. 2018. Polystyrene microplastics alter the behavior, energy reserve and nutritional composition of marine jacopever (Sebastes schlegelii). J. Hazard. Mat., 360: 97-105.https://doi.org/10.1016/j.jhazmat.2018.07.110

ZARBAN, A., TAHERI, F., CHAHKANDI, T., SHARIFZADEH, G., \& KHORASHADIZADEH, M. 2009. Antioxidant and radical scavenging activity of human colostrum, transitional and mature milk. J. Clin. Biochem. Nutr., 45(2): 150-154. http:// dx.doi.org/10.3164/jcbn.08-233. 